\title{
CARDIOVASCULAR MANIFESTATIONS OF HIV INFECTED PATIENTS: RESULTS OF A SINGLE CENTRE STUDY FROM A TERTIARY CARE CENTRE
}

\author{
Rohit Patil ${ }^{1}$, Vinayak M. Sawardekar², Snehal Killedar³, Shriram Nawade4, Vijeta Bagade5, V. K. Joglekar6, Prateek Chaudhary ${ }^{7}$, \\ Saurabh Patle 8
}

\begin{abstract}
${ }^{1}$ Assistant Professor, Department of Medicine, Grant Government Medical College and Sir JJ Group of Hospitals, Mumbai. ${ }^{2}$ Associate Professor, Department of Medicine, Grant Government Medical College and Sir JJ Group of Hospitals, Mumbai. 33 rd Year Junior Resident, Department of Paediatrics, Holy Family Hospital, Bandra, Mumbai.

${ }^{4}$ Assistant Professor, Department of Medicine, Grant Government Medical College and Sir JJ Group of Hospitals, Mumbai. ${ }_{5}^{5}$ Assistant Professor, Department of Medicine, Grant Government Medical College and Sir JJ Group of Hospitals, Mumbai. ${ }^{6}$ Professor and HOD, Department of Medicine, Grant Government Medical College and Sir JJ Group of Hospitals, Mumbai. ${ }^{7}$ Assistant Professor, Department of Medicine, Grant Government Medical College and Sir JJ Group of Hospitals, Mumbai. ${ }^{8}$ Assistant Professor, Department of Medicine, Grant Government Medical College and Sir JJ Group of Hospitals, Mumbai.
\end{abstract}

\section{ABSTRACT}

\section{BACKGROUND}

To study cardiac diseases in Human Immunodeficiency (HIV) infected patients and examine correlations of cardiovascular manifestations with CD4 counts and Anti-Retroviral Therapy (ART).

\section{MATERIALS AND METHODS}

In this cross-sectional study, HIV seropositive patients admitted in medicine ward were evaluated for presence of cardiac diseases by clinical examination and non-invasive cardiovascular investigation (chest x-ray, ECG and ECHO).

\section{RESULTS}

Fifty patients (mean age 37.36 years) were included. A total of $64 \%$ had Acquired Immune Deficiency Syndrome (AIDS), while $46 \%$ were on ART. Cardiac disorders were detected in 52\% patients; however, only $6 \%$ patients were symptomatic. Systolic dysfunction, diastolic dysfunction, pericardial effusion, dilated cardiomyopathy, pulmonary hypertension and cardiac tumour were detected in 5 (10\%), $16(32 \%), 6(12 \%), 3(6 \%), 4(8 \%)$ and $1(2 \%)$ patients respectively. In 39 (78\%) patients Electrocardiogram (ECG) was normal, whereas 11 (22\%) patients showed abnormalities in the ECG. The abnormalities included sinus tachycardia 7 (14\%), Ischaemic Heart Disease (IHD) 2 (4\%), Left Ventricular Hypertrophy (LVH) 1 (2\%) and low voltage complexes 1 (2\%). Cardiomegaly was detected in $3(6 \%)$ patients. Lower CD4 count was not associated with cardiac disorders $\left(x^{2}=12 ; p=0.213\right)$, but was associated with pericardial effusion $\left(x^{2}=28\right.$ and $\left.\mathrm{p}=0.032\right)$. Lower CD4 count was significantly associated with cardiomyopathy (table $\left.3 ; x^{2}=54 ; p=0.000\right)$, but not with diastolic dysfunction $\left(x^{2}=50 ; p=0.394\right)$. ART status was not associated with cardiomyopathy $\left(x^{2}=6 ; p=0.199\right)$ or diastolic dysfunction $\left(x^{2}=0.995 ; p=0.318\right)$.

\section{CONCLUSION}

Cardiac disorders are common in HIV infected patients, but only few are symptomatic. Non-invasive investigations help in early diagnosis of asymptomatic cardiac disorders.

\section{KEYWORDS}

ART, AIDS, Cardiac Disorders, CD4 Count, HIV.

HOW TO CITE THIS ARTICLE: Patil R, Sawardekar VM, Killedar S, et al. Cardiovascular manifestations of HIV infected patients: results of a single centre study from a tertiary care centre. J. Evolution Med. Dent. Sci. 2017;6(11):837-841, D0I: $10.14260 /$ Jemds/2017/182

\section{BACKGROUND}

The prevalence of Human Immunodeficiency Virus (HIV) in India, adult (15 - 49 years) is $0.26 \%$ and has shown steady decline from 2001 till date. ${ }^{1}$ Human immunodeficiency virus is known to cause significant morbidity and mortality due to virus itself (HIV), opportunistic infections or cancers.

Financial or Other, Competing Interest: None.

Submission 12-01-2017, Peer Review 25-01-2017,

Acceptance 28-01-2017, Published 06-02-2017.

Corresponding Author:

Dr. Vinayak M. Sawardekar,

Associate Professor

Department of Medicine,

Grant Government Medical College and

Sir JJ Group of Hospitals,

Mumbai.

E-mail: vinayaks1812@gmail.com

DOI: $10.14260 /$ jemds $/ 2017 / 182$

\section{(c) $(1) \ominus$}

Complex interactions of several factors result in clinical and pathologic abnormalities in various organ systems. ${ }^{2}$ Some of the common causes of death among hospitalised HIV patients include tuberculosis (extra-pulmonary and pulmonary), Cryptococcal meningitis, Pneumocystis jirovecii pneumonia, hepatic disease, alcoholic liver disease and cardiac disease. ${ }^{3}$ Cardiovascular Disease (CVD) is one of the important causes of morbidity among HIV-infected patients. Untreated HIV and specific Antiretroviral Therapy (ART) can have adverse impact on the cardiovascular risk. Treatment with Highly Active Anti-Retroviral Therapy (HAART) is important, because the long-term effects of treatment with potent HAART provide more benefits compared to the adverse impact on cardiovascular risks. ${ }^{4}$ A study from Pune showed $2.9 \%$ deaths due to cardiovascular disorders in hospitalised patients with HIV. ${ }^{3}$ Many studies $2,5-7$ from India have evaluated the cardiovascular disease pattern in HIV infected patients. Some of them have also evaluated the association of 
CD4 count with CVD. ${ }^{2,6}$

However, data from Indian studies evaluating association of CVD with ART and studies evaluating cardiac profile of HIV infected patients from Western India are limited.

\section{Objective}

To study the prevalence and types of cardiac disease in Human Immunodeficiency Virus (HIV) infected patients and examine correlations of cardiovascular manifestations with CD4 counts.

\section{MATERIALS AND METHODS}

In this cross-sectional study conducted from 1st June 2012 to 31st June 2014 at Tertiary Care Hospital in Maharashtra, HIV seropositive patients were included after clearance of study protocol from the Institutional Ethical Committee and written informed consent. Patients with congenital heart disease and pre-existing heart disease, those with hypertension diagnosed before HIV detections and HIV positive patients with diabetes were excluded. A detailed clinical profile including detailed history, general physical examination and systemic examination was conducted for each patient with special emphasis on cardiovascular system. Routine investigations including CD4 count were obtained for all the patients. All patients were subjected to non-invasive cardiovascular investigation, i.e. chest $\mathrm{x}$-ray, Electrocardiogram (ECG) and echocardiography. Angiograms were not done due to the cost considerations. Cardiac-tothoracic width ratio above 50 percent was considered as the criterion for diagnosis of cardiomegaly.8,9 A Philips machine with 8 - $3 \mathrm{MHz}$ variable frequency transducer was used for Mmode and B-mode echocardiographic and cardiac Doppler examination. Using Doppler evaluation for early mitral flow and late mitral flow their ratio, isovolumetric relaxation time, declaration time, systolic and diastolic functions were analysed. Dilated cardiomyopathy was defined as the presence of diffuse left ventricular hypokinesia (ejection fraction, < 45 percent) and dilatation (left ventricular enddiastolic volume index, $>80 \mathrm{~mL}$ per square meter). ${ }^{10}$ Systolic dysfunction was diagnosed when the Ejection Fraction (EF) was less than $50 \%$. The ejection fraction was calculated as the ratio of the stroke volume to the end diastolic volume. Diastolic dysfunction was defined as impaired relaxation [Deceleration Time (DT) $>240 \mathrm{msec}$. and Isovolumetric Relaxation Time (IVRT) > 90 msec. E wave, i.e. early peak in the transmitral flow profile/A wave i.e. late peak (or atrial) in the transmitral flow profile $\mathrm{E} / \mathrm{A}<1.0)]$, pseudonormal pattern (DT 160 - 200 msec., IVRT < 90 msec E/A 1 - 1.5) or restrictive filling (DT $<160 \mathrm{msec}$., IVRT $<70 \mathrm{msec}$. E/A $>$ 1.5). ${ }^{11}$ A systolic pulmonary artery pressure greater than 40 $\mathrm{mmHg}$, which corresponds to a tricuspid regurgitant velocity on Doppler echocardiography of 3.0 to $3.5 \mathrm{~m} / \mathrm{sec}$, was the criteria for pulmonary hypertension. ${ }^{12}$

\section{Statistical Analysis}

Categorical data is presented as number and percentages, whereas continuous variables are presented as mean (SD). Association between CD4 count and cardiac disorders and ART status and cardiac disorders was evaluated by using chi square test.

\section{RESULTS}

The study included a total of 50 patients with mean age of $37.36(+10.53)$ years. The baseline characteristics of patient population are described in Table 1 .

\begin{tabular}{|c|c|}
\hline Parameter & Results \\
\hline Mean age $(+\mathrm{SD})$ years & $37.36(+10.53)$ \\
\hline Male n (\%) & $32(64 \%)$ \\
\hline Female n $(\%)$ & $18(36 \%)$ \\
\hline $\begin{array}{l}\text { Age Group } \\
\bullet \quad 15-49 \text { years } \\
\bullet \quad>50 \text { years } \\
\end{array}$ & $\begin{array}{c}42(85 \%) \\
8(15 \%) \\
\end{array}$ \\
\hline $\begin{array}{l}\text { Mean CD4 Count n (\%) } \\
\text { - } \quad 1-200 \text { cells } / \mu \mathrm{L} \\
\text { - } \quad 201-350 \text { cells } / \mu \mathrm{L} \\
\text { - } \quad>350 \text { cells } / \mu \mathrm{L}\end{array}$ & $\begin{array}{c}32(64 \%) \\
13(26 \%) \\
5(10 \%)\end{array}$ \\
\hline Patients with AIDS n (\%) & $32(64 \%)$ \\
\hline Patients on ART n (\%) & $23(46 \%)$ \\
\hline
\end{tabular}

Eighty five percent patients were between $15-49$ years of age, whereas $15 \%$ were > 50 years. A total of $64 \%$ had AIDs, while $46 \%$ were on ART.

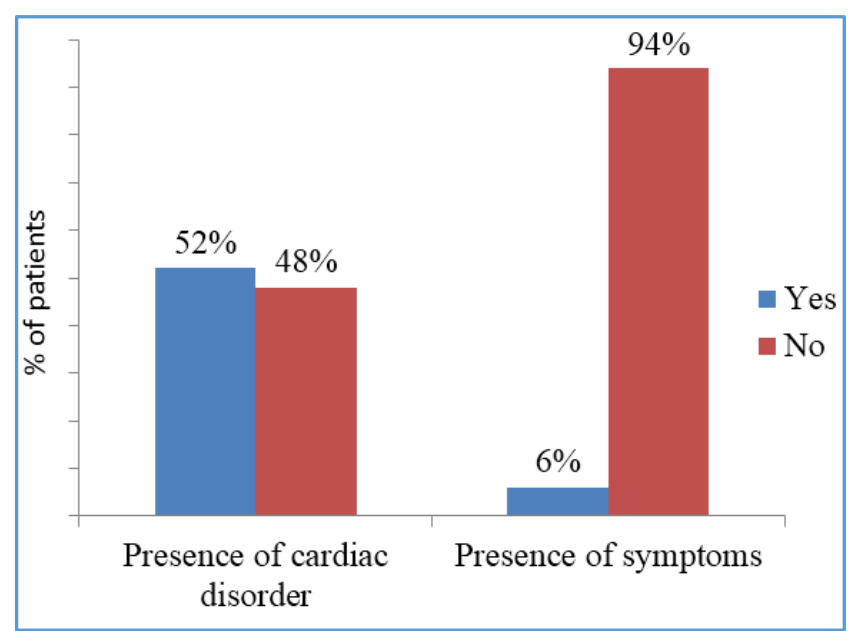

Figure 1. Prevalence and Symptoms of Cardiac Disorders in HIV Patients

Cardiac disorders were detected in $52 \%$ patients; however, only $6 \%$ patients were symptomatic.

\begin{tabular}{|c|c|c|c|}
\hline $\begin{array}{c}\text { Cardiac } \\
\text { Disorder }\end{array}$ & $\begin{array}{c}\text { Clinical } \\
\text { Detection } \\
\text { N (\%) }\end{array}$ & $\begin{array}{c}\text { Detection of } \\
\text { Echocardiography } \\
\text { N (\%) }\end{array}$ & $\begin{array}{c}\text { Total } \\
\text { N (\%) }\end{array}$ \\
\hline $\begin{array}{c}\text { Systolic } \\
\text { dysfunction }\end{array}$ & $1(2 \%)$ & $4(8 \%)$ & $5(10 \%)$ \\
\hline $\begin{array}{c}\text { Diastolic } \\
\text { dysfunction }\end{array}$ & 0 & $16(32 \%)$ & $\begin{array}{c}16 \\
(32 \%)\end{array}$ \\
\hline $\begin{array}{c}\text { Pericardial } \\
\text { effusion }\end{array}$ & $1(2 \%)$ & $5(10 \%)$ & $6(12 \%)$ \\
\hline $\begin{array}{c}\text { Dilated } \\
\text { cardiomyopathy }\end{array}$ & $1(2 \%)$ & $2(4 \%)$ & $3(6 \%)$ \\
\hline $\begin{array}{c}\text { Pulmonary } \\
\text { hypertension }\end{array}$ & 0 & $4(8 \%)$ & $4(8 \%)$ \\
\hline Cardiac tumour & 0 & $1(2 \%)$ & $1(2 \%)$ \\
\hline \multicolumn{2}{|c|}{ Table 2. Types of Cardiac Abnormalities (n= 50) } \\
\hline
\end{tabular}


Systolic dysfunction, diastolic dysfunction, pericardial effusion, dilated cardiomyopathy, pulmonary hypertension and cardiac tumour were detected in 5 (10\%), 16 (32\%), 6 $(12 \%), 3(6 \%), 4(8 \%)$ and $1(2 \%)$ patients respectively. The detection rates of these cardiac disorders with clinical examination and echocardiography are given in Table 2 .

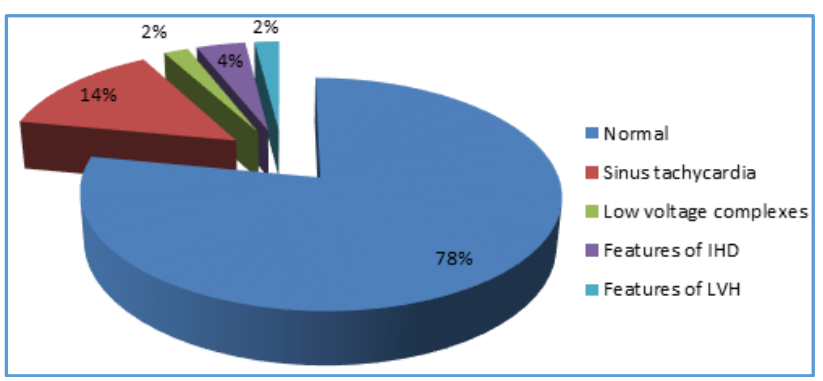

Figure 2. ECG Finding

In $39(78 \%)$ patients, ECG was normal, whereas $11(22 \%)$ patients showed abnormalities in the ECG. The abnormalities included sinus tachycardia 7 (14\%), features of IHD 2 (4\%), features of LVH 1 (2\%) and low voltage complexes $1(2 \%)$ (Figure 2).

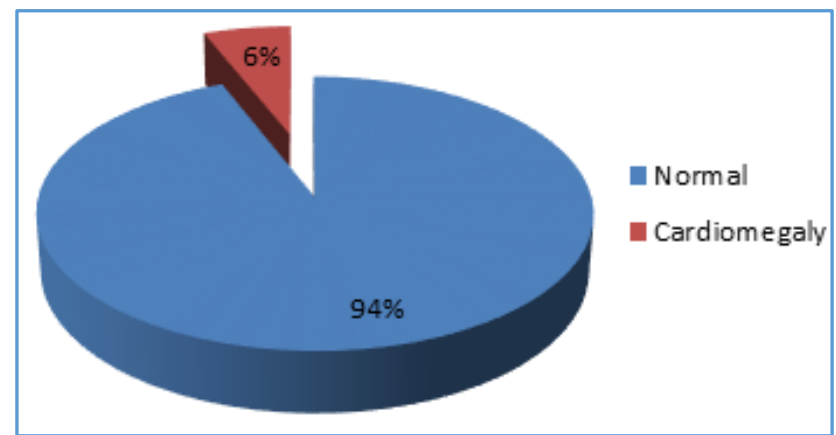

Figure 3. Detection of Cardiomegaly on X-Ray

Cardiomegaly was detected in $3(6 \%)$ patients, whereas X-ray findings were normal in 47 (94\%) patients (Figure 3).

\begin{tabular}{|c|c|c|c|}
\hline & \multicolumn{2}{|c|}{ Cardiac Disorder } & \multirow[t]{3}{*}{ P value } \\
\hline & Symptomatic Cardiac Disorder N (\%) & Asymptomatic Cardiac Disorder N (\%) & \\
\hline $\begin{aligned} & \text { CD4 count } \\
< & 200 \text { cells } / \mu \mathrm{L} \\
> & 200 \text { cells } / \mu \mathrm{L}\end{aligned}$ & $\begin{array}{c}3(6 \%) \\
0\end{array}$ & $\begin{array}{c}19(38 \%) \\
4(8 \%)\end{array}$ & \\
\hline & Cardiac Disorder Absent & Cardiac Disorder Present & \\
\hline $\begin{array}{c}\text { CD4 Count } \\
1-200 \text { cells } / \mu \mathrm{L} \\
201-350 \text { cells } / \mu \mathrm{L} \\
>350 \text { cells } / \mu \mathrm{L} \\
\end{array}$ & $\begin{array}{l}21(42 \%) \\
11(22 \%) \\
35(70 \%) \\
\end{array}$ & $\begin{array}{c}11(22 \%) \\
2(4 \%) \\
15(30 \%) \\
\end{array}$ & 0.213 \\
\hline & $\begin{array}{c}\text { Pericardial Effusion } \\
\text { Present } \\
\text { N (\%) }\end{array}$ & $\begin{array}{c}\text { Pericardial Effusion } \\
\text { Absent } \\
\text { N (\%) }\end{array}$ & \\
\hline $\begin{array}{l}\text { Mild } \\
\text { Moderate } \\
\text { Severe }\end{array}$ & $\begin{array}{c}6(12 \%) \\
4(66.66 \%) \\
1(16.66 \%) \\
1(16.66 \%) \\
\end{array}$ & $44(88 \%)$ & \\
\hline $\begin{array}{c}\text { CD } 4 \text { count } \\
1-200 \text { cells } / \mu \mathrm{L} \\
201-350 \text { cells } / \mu \mathrm{L} \\
>350 \text { cells } / \mu \mathrm{L} \\
\end{array}$ & $\begin{array}{c}5(15.62 \%) \\
1(7.69 \%) \\
0 \\
\end{array}$ & $\begin{array}{c}27(84.37 \%) \\
12(92.3 \%) \\
5(100 \%) \\
\end{array}$ & 0.032 \\
\hline & $\begin{array}{c}\text { Cardiomyopathy } \\
\text { Present } \\
\text { N (\%) } \\
\end{array}$ & $\begin{array}{c}\text { Cardiomyopathy } \\
\text { Absent } \\
\mathrm{N}(\%) \\
\end{array}$ & \\
\hline $\begin{array}{c}\text { CD } 4 \text { Count } \\
1-200 \text { cells } / \mu \mathrm{L} \\
201-350 \text { cells } / \mu \mathrm{L} \\
>350 \text { cells } / \mu \mathrm{L}\end{array}$ & $\begin{array}{c}3(9.38 \%) \\
0 \\
0\end{array}$ & $\begin{array}{c}29(90.62 \%) \\
13(100 \%) \\
5(100 \%)\end{array}$ & 0.000 \\
\hline & $\begin{array}{c}\text { Diastolic Dysfunction } \\
\text { Present } \\
\text { N (\%) } \\
\end{array}$ & $\begin{array}{c}\text { Diastolic Dysfunction } \\
\text { Absent } \\
\text { N (\%) } \\
\end{array}$ & \\
\hline $\begin{array}{c}\text { CD } 4 \text { Count } \\
1-200 \text { cells } / \mu \mathrm{L} \\
201-350 \text { cells } / \mu \mathrm{L} \\
>350 \text { cells } / \mu \mathrm{L} \\
\end{array}$ & $\begin{array}{c}12(25 \%) \\
4(8 \%) \\
0 \\
\end{array}$ & $\begin{array}{c}20(40 \%) \\
9(18 \%) \\
5(10 \%) \\
\end{array}$ & 0.394 \\
\hline & $\begin{array}{c}\text { Cardiomyopathy Present } \\
\text { N (\%) } \\
\end{array}$ & $\begin{array}{c}\text { Cardiomyopathy Absent } \\
\text { N (\%) } \\
\end{array}$ & \\
\hline On ART & $3(13.04 \%)$ & $20(86.95 \%)$ & 0.199 \\
\hline Not on ART & 0 & $27(100 \%)$ & \\
\hline & $\begin{array}{c}\text { Diastolic Dysfunction Present } \\
\text { N (\%) }\end{array}$ & $\begin{array}{c}\text { Diastolic Dysfunction Absent } \\
\mathrm{N}(\%)\end{array}$ & \\
\hline On ART & $9(18 \%)$ & $14(28 \%)$ & 0318 \\
\hline Not on ART & $7(14 \%)$ & $20(40 \%)$ & 0.310 \\
\hline
\end{tabular}


Lower CD4 count was not found to be significantly associated with cardiac disorders (Table $3 ; \mathrm{x}^{2}=12 ; \mathrm{p}=$ 0.213 ); however, it was significantly associated with presence of pericardial effusion (Table $3 ; x^{2}=28$ and $p=0.032$ ). Lower CD4 count was also significantly associated with cardiomyopathy (Table $3 ; \mathrm{x}^{2}=54 ; \mathrm{p}=0.000$ ), but not with diastolic dysfunction (Table $3 ; x^{2}=50 ; p=0.394$ ). ART status was not associated with presence of cardiomyopathy (Table $3 ; x^{2}=6 ; p=0.199$ ) or diastolic dysfunction (Table $3 ; x^{2}=$ $0.995 ; \mathrm{p}=0.318$ ).

\section{DISCUSSION}

Cardiac disease is one of the important comorbidities among HIV infected patients. Various Indian as well as global studies have shown presence of cardiac disorders in HIV patients. $2,5-7,13$ We performed a single centre study to evaluate presence of cardiac disorders in HIV patients admitted in a tertiary hospital. Our study population was predominantly below 50 years of age. A total of $64 \%$ patients had AIDS. Referral pattern and tertiary care centre facility may explain the high prevalence of AIDS in our study.

We observed a high prevalence of cardiac disorders in HIV patients, but only a few were symptomatic. The findings are in accordance with literature showing symptomatic cardiac disease being far less common compared to the asymptomatic cardiac disease in HIV infected patients.14,15 The cardiac disorders identified in HIV patients in our study were diastolic dysfunction, pericardial effusion, systolic dysfunction, pulmonary hypertension, dilated cardiomyopathy and cardiac tumour. A study has shown high prevalence of non-calcified coronary artery plaque in men infected with HIV, 13 increasing the chances of ischaemic heart disease. In our study $22 \%$ patients had abnormal electrocardiogram, mainly in the form of sinus tachycardia. Ischaemic changes were seen only in $4 \%$ patients. The lower rate of ECG abnormalities may be explained by younger cohort and exclusion criteria of diabetes and hypertension in this study.

Lower CD4+ T-cell count is associated with higher prevalence of cardiac problem in male patients. ${ }^{13} \mathrm{We}$ evaluated correlation between low CD4 count and presence of cardiac disorders. Our study demonstrated a high prevalence of pericardial effusion in AIDS subjects in agreement with other echocardiography ${ }^{16,17}$ and autopsy 18 investigations showing high prevalence of pericardial effusion in patients with AIDS. Large, haemodynamically significant effusion is less common than small effusions. ${ }^{14}$ In our study too, majority of effusions were small and asymptomatic. Only one patient had effusion, which required pericardial drainage. He had large pericardial effusion of tuberculous aetiology. A study ${ }^{19}$ has shown mycobacterial infection as the most common aetiology of pericardial effusion. Pericardial effusion in our study was also statistically significant with haemoglobin level and heart rate ( $p=0.021$ and $p=0.000$ respectively). The prevalence of pericardial effusion in our study was also related to the low CD4 count.

HIV/AIDS is an important cause of dilated cardiomyopathy, mostly because of the myocarditis. ${ }^{20}$ Opportunistic infections, direct HIV infection of the myocyte, cachexia and drug-induced cardiotoxicity with agents like Zidovudine are possible contributing causes of myocarditis and dilated cardiomyopathy.20-22 Other drugs such as doxorubicin used for the treatment of Kaposi's sarcoma and foscarnet sodium used to treat cytomegalovirus oesophagitis in AIDS patients have also been implicated in the cardiomyopathy. 20 The reported prevalence of dilated cardiomyopathy is about $10 \%-30 \%$ by echocardiographic and autopsy studies.23 In our study, the prevalence of dilated cardiomyopathy was lower $(6 \%)$ than the reported rates. Dilated cardiomyopathy occurs late in the course of disease and is usually associated with a significantly lower CD4 count.24,25 In our study all patients with cardiomyopathy had CD4 count less than 200, which is in accordance with prior findings. Drug toxicity is another important cause of cardiomyopathy in these patients. ${ }^{20}$ In our study lower CD4 counts was significantly associated with cardiomyopathy, but ART status was not associated with cardiomyopathy. We did not perform subgroup analysis of cardiomyopathy patients, because of very small sample size. Systolic dysfunction was detected in $10 \%$ in our study compared to $23.3 \%$ in another study. ${ }^{26}$ In present study, dilated cardiomyopathy is statistically significant with haemoglobin, heart rate and systolic blood pressure with $P$ value of $0.006,0.032$ and 0.048 respectively.

Pulmonary hypertension in HIV infected patients can be primary or secondary. The causes of secondary pulmonary hypertension include left-sided heart disease, respiratory dysfunction or chronic thrombotic/embolic disorders. Idiopathic pulmonary arterial hypertension may occur due to vascular smooth muscle cell hyperplasia secondary to cytokines. In our study, pulmonary hypertension was seen in $8 \%$ patients compared to $4.7 \%$ in another study. ${ }^{27}$ All the patients had cardiac pathology, which might have contributed to the pulmonary hypertension. In our study the prevalence of diastolic dysfunction was the most common cardiac manifestation, but still was lesser compared to other studies. $^{25,28}$ Diastolic dysfunction was asymptomatic and incidental finding in all the patients in present study. Lower CD4 count and ART status was not significantly associated with diastolic dysfunction in our study. Pericardial effusion was the second most common cardiac disorder, majorly mild in nature. Lower CD4 count was significantly associated with the presence of pericardial effusion, cardiomyopathy, but not with diastolic dysfunction. ART status was not significantly associated with cardiac disorder.

Overall, our study findings show that patients with HIV infection can have a variety of cardiovascular manifestations. Systolic dysfunction, diastolic dysfunction, pericardial effusion, dilated cardiomyopathy and pulmonary hypertension were the common abnormalities reported in our study. Cardiovascular disease in HIV infected patients may be attributed to virus itself, the effects of anti-retroviral medications or altered immune mechanisms associated with the infection. Stratification of cardiovascular risk and cardiovascular monitoring in HIV patients pose a challenge to physicians. Our study provides some insights into the pattern of cardiovascular diseases and their association with CD4 count and ART.

Small sample size, single centre study and inclusion of only hospitalised patients are the limitations of our study, which makes it difficult to generalise the findings to the entire population of HIV infected patients. Considering this, we suggest routine implementation of standard non-invasive 
cardiovascular screening methods among HIV infected hospitalised patients and application of interventions to reduce the risk and adverse consequences.

\section{CONCLUSION}

Cardiac disorders are prevalent in HIV infected patients; however, only few HIV patients with cardiac disorders are symptomatic. Lower CD4 count was not significantly associated with the overall prevalence of cardiovascular manifestations. However, it was significantly associated with pericardial effusion and cardiomyopathy. Non-invasive investigations like echocardiography help in the early diagnosis of asymptomatic cardiac disorders. Efforts should be done to diagnose cardiac disorder to avoid the subsequent complications in these patients.

\section{REFERENCES}

[1] HIV data available at: http://www.naco.gov.in/sites/default/files/HIV\%20DA TA.pdf accessed on 29th December 2016.

[2] Kumar SP, Siddeswari R, Sridhar D, et al. Prevalence of cardiac manifestations in HIV infected patients correlating with CD4 count. International Journal of Scientific and Research Publications 2015;5(5):1-4.

[3] Sobhani R, Basvaraj A, Gupta A, et al. Mortality \& clinical characteristics of hospitalized adult patients with HIV in Pune, India. Indian J Med Res 2007;126(2):116-21.

[4] Palella FJ, Phair JP. Cardiovascular disease in HIV infection. Curr Opin HIV AIDS 2011;6(4):266-71.

[5] Guha S, Pande A, Mookerjee S, et al. Echocardiographic profile of ART naïve human immunodeficiency virus (HIV) infected patients in a tertiary care hospital in Kolkata. Indian Heart J 2010;62(4):330-4.

[6] Singh A, Das S, Dalai RK. Study of cardiac manifestations in patients with HIV infection and their correlation with CD4 count in Indian population. International Journal of Clinical Medicine 2012;3(3):178-83.

[7] Sarosh Kumar KK, Jayakumar B, Baiju R. A study of clinical profile of cardiac dysfunction in patients with HIV infection. Int J Res Med Sci 2016;4(12):5149-53.

[8] Gillespie ND, McNeil G, Pringle T, et al. Cross sectional study of contribution of clinical assessment and simple cardiac investigations to diagnosis of left ventricular systolic dysfunction in patients admitted with acute dyspnoea. BMJ 1997;314(7085):936-40.

[9] Grainger RG, Thomsen HS, Morcos SK, et al. Intravascular con-trast media radiology, CT and MRI. IN: Adam A, Dixon AK, (eds). Chapter 2. Grainger \& Allison's Diagnostic Radiology: A Textbook of Medical Imaging. $5^{\text {th }}$ edn. Philadelphia: Churchill Livingstone; 2008:31-54.

[10] Schiller NB, Shah PM, Crawford M, et al. Recommendations of quantitation of the left ventricle by two-dimensional echocardiography. American society of echocardiography committee on standards, subcommittee on quantitation of two-dimensional echocardiograms. J Am Soc Echocardiogr 1989;2(5):358-67.
[11] Oh JK, Seward JB, Tajik AJ. The Echo Manual. 2nd edn. Lippincott Williams and Wilkins 2006:p 431.

[12] Rich S (eds). Executive summary from the World Symposium on Primary Pulmonary Hypertension, Evian, France, September 6-10, 1998, co-sponsored by The World Health Organization.

[13] Post WS, Budoff M, Kingsley L, et al. Associations between HIV infection and subclinical coronary atherosclerosis. Ann Intern Med 2014;160(7):458-67.

[14] De Castro S, Migliau G, Silvestri A, et al. Heart involvement in AIDS: a prospective study during various stages of the disease. Eur Heart J 1992;13(11):1452-9.

[15] Estok L, Wallach F. Cardiac tamponade in a patient with AIDS: a review of pericardial disease in patients with HIV infection. Mt Sinai J Med 1998;65(1):33-9.

[16] Himelman RB, Chung WS, Chernoff DN, et al. Cardiac manifestations of human immunodeficiency virus infection: a two-dimensional echocardiographic study. J Am Coll Cardiol 1989;13(5):1030-6.

[17] Levy WS, Simon GL, Rios JC, et al. Prevalence of cardiac abnormalities in human immunodeficiency virus infection. Am J Cardiol 1989;63(1):86-9.

[18] Lewis W. AIDS: cardiac findings from 115 autopsies. Prog Cardiovasc Dis 1989;32(3):207-15.

[19] Gowda RM, Khan IA, Mehta NJ, et al. Cardiac tamponade in patients with human immunodeficiency virus disease. Angiology 2003;54(4):469-74.

[20] Barbaro G, Barbarini G. Human immunodeficiency virus \& cardiovascular risk. Indian J Med Res 2011;134(6):898-903.

[21] Herskowitz A, Willoughby SB, Baughman KL, et al. Cardiomyopathy associated with antiretroviral therapy in patients with HIV infection: a report of six cases. Ann Intern Med 1992;116(4):311-3.

[22] Lewis W, Grupp IL, Grupp G, et al. Cardiac dysfunction occurs in the HIV-1 transgenic mouse treated with zidovudine. Lab Invest 2000;80(2):187-97.

[23] Cohen IS, Anderson DW, Vermani R, et al. Congestive cardiomyopathy in association with the acquired immunodeficiency syndrome. $\mathrm{N}$ Engl J Med 1986;315(10):628-30.

[24] Herskowitz A, Willoughby SB, Vlahov D, et al. Dilated heart muscle disease associated with HIV infection. Eur Heart J 1995;16(suppl 0):50-5.

[25] Jacob AJ, Sutherland GR, Bird AG, et al. Myocardial dysfunction in patients infected with HIV: prevalence and risk factors. Br Heart J 1992;68(6):549-53.

[26] Mittal CM, Wig N, Mishra S, et al. Cardiac dysfunction in human immunodeficiency virus (HIV) infected patients in India. Int J Cardiol 2006;107(1):136-7.

[27] Reinsch N, Buhr C, Krings P, et al. Effect of gender and highly active antiretroviral therapy on HIV-related pulmonary arterial hypertension: results of the HIVHEART study. HIV Med 2008;9(7):550-6.

[28] Cardoso JS, Moura B, Martins L, et al. Left ventricular dysfunction in human immunodeficiency virus (HIV)infected patients. Int J Cardiol 1998;63(1):37-45. 